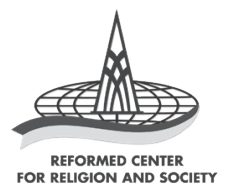

Societas Dei: Jurnal Agama dan Masyarakat Vol. 7, No. 2 (October 2020): 117-122

http://societasdei.rcrs.org/index.php/SD/issue/archive

p-ISSN: 2407-0556; e-ISSN: 2599-3267

DOI:10.33550/sd.v7i2.181

\title{
EDITORIAL
}

\section{VIRUS: SEBUAH DISKURSUS}

\author{
Semy Arayunedya \\ Reformed Center for Religion and Society, Jakarta \\ semyarayunedya@rcrs.org
}




\section{EDITORIAL}

"Apakah kebenaran itu?" merupakan sebuah pertanyaan klasik manusia sepanjang abad. Konon, barangsiapa mendapatkan jawaban ini maka manusia akan berbahagia karena mengenal jati dirinya dan hidup selaras dengan sesama dan alam raya. Sudah barang tentu jawaban ini tidak mudah diraih. Penggalian manusia akan kebenaran menempuh perjalanan terjal dan berkelok. Pena-pena yang menggoreskan huruf di lembaran sejarah mengisahkan ketegangan dan kerap menumpahkan darah. Lalu, lembaran seperti apa yang akan kita unjukkan bagi generasi mendatang mengenai pencarian akan kebenaran atas isu yang kita hadapi hari-hari ini?

Sepanjang tahun 2020, mayoritas populasi manusia di semua negara bergulat dengan bencana yang sama. Setidaknya wabah Covid-19 sudah menjangkiti lebih dari 35 juta manusia dan merengggut 1 juta jiwa. Selain jumlah korban yang tidak kunjung mengalami penurunan, yang membuat wabah ini menggemparkan adalah karena daya sengatnya mempengaruhi seluruh sisi kehidupan manusia. Selain tentu kesehatan yang langsung diserang, namun bidang lain seperti ekonomi, pendidikan, sosial, politik, militer, hingga teologi juga berjibaku dengan virus ini. Perdebatan mulai dari asal-usul, konspirasi, penanganan, hingga ekses seputar pandemi di wilayah negara-bangsa hingga rumah tangga menimbulkan diskursus tersendiri.

Negara-negara mencatatkan pertumbuhan ekonomi negatif sepanjang tahun ini. Indonesia sudah mengumumkan resesi pada bulan September 2020. Kritik semakin gencar terhadap sistem ekonomi dunia yang sering diaku sebagai perlambang kesejahteraan dengan deretan angka-angka Produk Domestik Bruto-nya. Walaupun belum ada alternatif yang menandingi, sistem ekonomi yang juga berjasa membawa manusia pada era globalisasi, teknologi, dan kemajuan industri ini tetap tak berkutik dan terlihat ringkih mengatasi bencana, lingkungan hidup, dan ketimpangan sosial-ekonomi.

Kemajuan ekonomi negara-negara Barat disertai kebangkitan ekonomi dunia ketiga juga mempengaruhi perilaku masyarakat. Salah satunya adalah manusia menjadi ahli konsumsi, jika terlalu kasar menyebut pelahap. Jika zaman modern menciptakan manusia-manusia yang otonom dan berkemajuan, maka zaman Pascamodern melahirkan manusia-manusia otonom dan berkemajuan yang berpakaian, bermobil, berapartemen serba wah dan hah. Manusia Modern dan Pascamodern sama-sama mengusung pemberhalaan pada otonomi manusia, hanya ditambahkan jubah yang lebih mewah. Manusia melihat sesama dan lingkungannya sebatas kacamata ekonomi. Setidaknya cara pandang ini terwujud nyata di dalam setiap kebijakan, keputusan, maupun tindakan keseharian pemerintah dan masyarakat. 
Anjuran untuk bekerja dan belajar dari rumah menimbulkan pro-kontra argumen masing-masing kubu yang disuguhkan dilema pilihan antara mengutamakan kesehatan, sosial, atau ekonomi.

Sejak infeksi virus terdeteksi oleh pemerintah Indonesia, enam bulan selanjutnya virus semakin meningkat dan belum menunjukkan tren penurunan. Keseharian masyarakat dan ketidaktegasan pemangku kebijakan disinyalir menyebabkan virus semakin menjalar. Bagi sebagian kalangan, masyarakat Indonesia itu bandel. Namun bagi kelompok berpenghasilan rendah, bekerja di luar maupun di dalam rumah bagai buah simalakama. Berpeluang dihinggapi virus jika bekerja di luar, sebaliknya tetap tidak imun jika mengisolasi diri di petak rumah karena lebih dari satu kepala keluarga tinggal dalam satu atap. Selain itu budaya kolektivis masih menjadi bagian dari masyarakat Indonesia yang sulit melepaskan kegiatan kekeluargaan dan kemasyarakatan. Dari segala polemik yang ada, pemerintah dengan segala daya upaya merespons keadaan.

Di sinilah, konstelasi politik di tengah badai Covid-19 mengalami dinamika unik. Di ruang diskusi, relasi sipil-militer menduduki kursi pemerintahan kembali mengemuka. Penunjukan sosok dari latar belakang militer atau kepolisian, baik yang purna maupun perwira, dalam ranah kepemimpinan sipil disorot. Pihak yang pro-kebijakan ini menilai bahwa seharusnya tidak perlu terlalu mempermasalahkan apakah jabatan diisi oleh purnawirawan atau sipil. Yang harus ditekankan adalah kemampuan dalam memimpin. Di Inggris maupun Amerika, beberapa pos dalam pemerintahan diisi dan dijalankan dengan baik oleh purnawirawan militer. Di samping, mayoritas masyarakat sipil di negara-negara tersebut tidak menjadikan hal itu sebagai isu serius.

Para pengamat di golongan seberang mengkhawatirkan kembalinya dwifungsi tentara atau dwifungsi kepolisian yang mulai trending menggantikan istilah sebelumnya. Mereka melihat bahwa ancaman dunia kontemporer, pun Indonesia, sudah tidak didominasi lagi dengan peperangan simetris. Namun alokasi anggaran negara yang masih didominasi oleh pertahanan dan kepolisian ketimbang kesehatan atau pertanian menunjukkan cara pandang yang berseberangan. Wabah, yang digolongkan sebagai ancaman nonmiliter dan menggerogoti kesehatan, semakin memperkuat argumen untuk mengoreksi watak militeristik. Pengarusutamaan watak ini juga tercermin dari kepemimpinan menangani pandemi yang dipercayakan pada unsur militer atau kepolisian, dan bukannya kepada para pakar di bidang epidemi atau virus.

Meskipun demikian, jejak pakar juga bukannya tanpa bercak. Para ilmuwan pernah meleset dalam memprediksi berhentinya pandemi dan 


\section{EDITORIAL}

belum menunjukkan hasil dalam upaya rekayasa sosial. Namun dalam pergulatan dengan virus, kinerja ilmuwan mulai dijunjung tinggi dan digantungkan harapan. Tentu saja tidak hanya peneliti di bidang kesehatan, melainkan juga statistika, informatika, ekonomi, dan bidang sosial lainnya.

Ketika sebagian manusia menggantungkan harapan pada cendekiawan, ada sebagian lain merebahkan dirinya pada para agamawan. Agar mengena dalam sanubari umat, para pemuka agama biasanya membumikan ayat-ayat suci untuk diterapkan dalam kehidupan sehari-hari, terlebih di masa pandemi. Di masa-masa krisis ini, para pemuka agama juga terlibat adu argumentasi. Ada sebagian pemimpin agama yang merasa mampu menghardik virus dan meramalkan kapan pandemi usai. Sebagian lainnya memandang remeh virus karena yang perlu ditakuti hanyalah Tuhan. Kelompok ini tetap menjalankan kegiatan keagamaan sehingga menjadi klaster baru penyebaran virus. Sikap-sikap tersebut dikecam oleh pihak lain - yang kebanyakan seagama - karena menganggap, baik pihak yang meramal maupun mengabaikan protokol kesehatan, telah memperkosa ayat dan bersikap fatalistic.

Artikel dari Jadi Sampurna Lima yang berjudul Milenialisme dan Covid19 mengawali sebuah diskusi di edisi kali ini dengan sebuah pengamatan terhadap kaum beragama, khususnya di dalam Kristen sendiri, yang mudah menyibukkan diri untuk menghubung-hubungkan bencana dengan kesudahan zaman ataukah dengan penghukuman Tuhan. Bencana memantik ragam pandangan mengenai eskatologi. Penulis memaparkan tiga pandangan eskatologi Kristen antara lain pramilenialisme, amilenialisme, dan pascamilenialisme. Penulis menunjukkan bahwa amilenialisme, sebagai pemahaman eskatologis, dapat menolong orang Kristen menyandarkan kepercayaan sepenuhnya kepada Allah. Pemahaman ini pula yang tetap mendorong orang Kristen berkarya mengelola bumi dengan bertanggungjawab sebagai wujud kasihnya terhadap Tuhan dan sesama. Walaupun tesisnya bertumpu pada amilenialisme sebagai opsi yang dianjurkan, kedua pandangan lain mengenai pascaamilenialisme dan pramilenialisme diulas dengan seimbang.

Beranjak dari diskusi tentang kepelbagaian pemikiran dalam satu agama, artikel kedua memasuki ranah diskusi di antara agama yang berbeda. Jessica Layantara berupaya mendedah Amica Censura: Pemikiran Nicholas Cusanus tentang Agama-Agama, Sebuah Refleksi dan Aplikasi terhadap Konflik Antaragama di Indonesia. Rohaniwan Katolik ini hidup ketika ketegangan antara Islam dan Katolik memuncak di Abad Pertengahan. Buku-buku karyanya yang berkutat pada konflik antaragama patut mendapat perhatian para pegiat perdamaian di Indonesia. Tesis penulis 
yang memosisikan Cusanus berada di tengah-tengah eksklusivisme dan pluralisme sehingga melahirkan refleksi dan merekomendasikan aplikasi bagi konflik antaragama di Indonesia merupakan hal yang menarik untuk disimak. Ekslusivisme dan pluralisme cenderung bertentangan satu sama lain daripada seakan-akan bertentangan. Bagaimana menjelaskan kontradiksi ini?

Edy Syahputra Sihombing berupaya menerangkan kedua pandangan tersebut dalam artikelnya yang berjudul Kesaksian Iman dalam Dialog Interreligius dan Teologi Interkultural. Penganut agama harus eksklusif yang berarti kukuh mempertahankan imannya tetapi sekaligus juga seorang pluralist yang dalam artian terbuka untuk mengenal dan berbagi satu sama lain di dalam masyarakat yang majemuk. Kesaksian iman justru menjadi pijakan bagi penganut masing-masing agama untuk berdialog. Tanpa itu, dialog hanya akan dipandang sebagai salah satu bentuk sinkretisme. Itu sebab, salah satu poin penelitian ini mendapati perbedaan antara dialog dan misi, walaupun tidak untuk dipisahkan. Jika dialog yang sehat justru menunjukkan kesaksian iman yang kuat maka misi berada pada jalur berlainan karena sikapnya dalam mempertahankan iman.

Misi tidak sedangkal berkanjang pada urusan konversi agama. Misi dalam agama Kristen adalah kisah Kerajaan Allah, di mana orang Kristen diundang ikut serta menjejakkan nilai-nilai kerajaan itu di bumi. Setiap langkah seorang Kristen di tanah yang dia pijak di situlah seharusnya ada kisah Kerajaan Allah, salah satunya mengenai keadilan ekonomi. Yohanes Tampubolon menujukan artikelnya kepada Misi Gereja di Era Kapitalisme Global: Eksplorasi Pelayanan Misi Yesus. Gereja saat ini perlu mengeksplorasi misi Yesus dan menyesap sari pengajaran-Nya dalam menghadapi kapitalisme global. Ketimpangan ekonomi dan politik - yang disebabkan oleh kapitalisme ini - menggerakkan penulis untuk menjelaskan seluk-beluk misi gereja, misi pelayanan Yesus di tengah konteks ekonomi dan politik zaman imperium Romawi, dan merumuskan model misi gereja di tengah cengkeraman kapitalisme global.

Negara yang seharusnya memiliki kekuatan untuk memperkecil ketimpangan ekonomi dan politik justru seringkali kedodoran dan bahkan melanggengkan ketidakadilan. Gereja, yang berada di sebuah wilayah yang aman maupun penuh ancaman, tetap tidak boleh menghilangkan perannya menghadirkan keadilan. Suarbudaya Rahadian dan Fially Fallderama menguraikan penelitian mereka mengenai Sikap Kritis terhadap Kekuasaan dalam Tradisi Calvinist: Sebuah Kajian Historis-Teologis tentang Kekritisan Gereja terhadap Pemerintah untuk Mewujudkan Regnum Christi. Kedua penulis memberikan catatan pada gereja di jalur calvinist yang enggan bersikap 
kritis terhadap pemerintah dan berargumen bahwa gereja-gereja calvinist mengalami kelupaan terhadap pemikiran teologi John Calvin, secara khusus dalam eklesiologi dan etika politik sehingga menumpulkan dimensi kesadaran/kekritisan gereja ketika berhadap-hadapan dengan pemerintah. Penelitian ini bertujuan memberi sumber daya teologis dari akar pemikiran John Calvin untuk memberikan perangkat analisis kritis serta landasan etis dalam memahami relasi gereja dengan pemerintah dalam konteks Indonesia.

Wabah virus mendirikan panggungnya sendiri mengenai diskusi akan kebenaran. Kritik ataupun pembelaan menimbulkan pertentangan - yang seringkali dianggap memicu kegaduhan - mengenai gagasan di berbagai bidang ini justru memperoleh ruang untuk mendiskusikan kebenaran dan bukannya sebuah kontes membusungkan manusia yang tergagah, terkuat, terpandai, atau terhebat. Manusia tidak terpanggil untuk itu. Kepingan dan kutipan dari tiap pertentangan gagasan bukanlah recehan melainkan ajang penelitian mencari kebenaran. Sebagaimana halnya kalangan cerdik pandai yang senantiasa ikut serta berjibaku dengan wacana yang tergulir maka semestinya kita menyadari bahwa goresan peristiwa sejarah bermula dari bahasan ide-ide para pemikir. Dus, benturan gagasan adalah sebuah keniscayaan.

Selamat berdiskusi! 